\title{
The Trends and Influential Factors of Children's Use of Outdoor Environments: A Review
}

\author{
Nor Fadzila Aziz'1 Ismail Said² \\ ${ }^{1} \mathrm{PhD}$ Candidate, ${ }^{2}$ Associate Professor, \\ Faculty of Built Environment, \\ Universiti Teknologi Malaysia, Malaysia \\ fadzilanor@gmail.com, b-ismail@utm.my
}

\begin{abstract}
In the past two decades, there has been a raft of research on children's behaviour and their interaction with outdoor environment. The aim of this paper is to present a synthesis of 30 studies from 1985 to 2010 on children's use of outdoor environments. The aspects taken into consideration include methodological issues and factors that influence the use of outdoor environments. The trends of the studies are discussed. In summary, the children's place preferences and play behaviours in the outdoor environments are influenced by their developmental needs, individual, physical and social factors.
\end{abstract}

Keywords: Children; outdoor environments; influential factors; Ecological Model

eISSN 2514-751X @ 2017 The Authors. Published for AMER ABRA by e-International Publishing House, Ltd., UK. This is an open-access article under the CC BY-NC-ND license (http://creativecommons.org/licenses/by-ncnd/4.0). Peer-review under responsibility of AMER (Association of Malaysian Environment-Behaviour Researchers), ABRA (Association of Behavioural Researchers on Asians) and CE-Bs (Centre for EnvironmentBehaviour Studies), Faculty of Architecture, Planning \& Surveying, Universiti Teknologi MARA, Malaysia.

https://doi.org/10.21834/aje-bs.v2i5.226 


\subsection{Introduction}

In recent years there has been a growing discourse regarding playing outdoors as both a need and right of young children, and central to their well-being. The body of the research considering children's rights to play in the outdoor environment has raised especially investigation on children's play behaviour and their interaction with outdoor environment. These developments have occurred in a large extent due to a range of phenomena that are hindering children's play experiences at outdoor environments including rapid urbanisation, increase in street traffic, badly planned urban environments, pollution, pressures of educational accomplishment, creation of indoor play technologies and a lack of awareness about the importance of play for children's development and well-being (Kernan, M. 2010). As a result of these changes, it is increasingly uncommon to see groups of children walking, running or playing on the outdoor environments without adult's supervision. Such changes certainly have profound repercussions on the psycho-physical development of children (Castonguay, G. \& Jutras, S., 2010).

Children need to have the environment that addresses them, challenges them, and provides something for them to observe, to think about, to make choices, to attract their attention, to engage in their favourite activities and to give them the opportunity to meet friends. They also need the freedom to explore and to satisfy their curiosity about the world. The opportunity to be in the outdoor environment is important for the development of children's motor and cognitive skills, interpersonal attitudes and emotions. The differences in outdoor environments such as neighborhoods, parks, playgrounds, school grounds and natural environments can comprise rich sources of stimulation and affordances for children. Affordances refer to the functional properties of the environments offering a child to interact actively with the environment (Gibson, J.J., 1979; Heft, H., 1988; Kytta, M., 2002, 2004). For example, flat and smooth surfaces can allow for cycling, running and skating; smooth slopes can allow for skateboarding, while shrubs can allow for a hide and seek game. Affordances and other stimulation provided by the environment allow and support children's exploration and play.

Play has been central to the study of children's outdoor environments. It is the primary mechanism through which children become familiar with their environment (Matthews, M.H., 1992). Play allows children to stretch themselves cognitively, physically and socially. Children rely on their imaginations while playing, and they learn to use their thoughts to guide their behaviours (McDevitt, T.M., \& Ormrod, J.E., 2002). Playing in the outdoor environments that offer various affordances can stimulate their sense and generate cognitive skills (Olds, A.R., 1989). They learn through three modes of learning which are cognitive, affection and evaluation (Kellert, S.R., 2002) from the elements in the outdoor environments, either natural or man-made. In summary, the outdoor environment offers unique opportunities for children to engage in active and creative play as well as a ground to interact with friends.

This paper presents a synthesis of 30 studies from 1985 to 2010 on children 
experiencing various outdoor environments. The aim of this paper is to understand the trend of studies concerning children and their outdoor environments and factors that influence their decisions and selections of an outdoor place to play.

\subsection{Methodology}

Literature was selected based on different disciplines including children's geographies, children's developments, environmental psychology, environmental education, health and landscape architecture. Computerised searches were conducted using online databases from Science Direct, SAGE, Scopus and JSTOR. Combinations of the following key words were used to guide the search: children, outdoor environment, physical environment, physical activity, development, health and nature.

Papers were drawn primarily from those published between 1985 and 2010 and included theoretical, review, and empirical articles, both quantitative and qualitative. Literature was chosen to illustrate the breadth of knowledge available about the children experiencing outdoor environments and the impact on children's developments. A greater emphasis was placed on literature that addressed the relationship between individual level factors, physical and social environments that influence children use of outdoor environments and their behaviours. The aspects taken into consideration in review included methodological issues and factors that influenced the use of outdoor environments.

\subsection{Results and Discussions}

Previous studies on children's experiencing outdoor environments were taken in varying settings: the neighbourhood (e.g. Peterson, L. et al., 1991; Kytta, M., 2002, 2004; Castonguay, G., \& Jutras, S., 2009, 2010), playground (Wilkinson, P.F, 1985; Lowry, P., 1993;), school ground (Harvey, M.R., 1989; Dyment, J.E. et al., 2009), public place (Lennard, H.L., \& Lennard, S.H.C., 1992), street (Tyler, F.B. et al., 1987) and natural environment (Fjørtoft, I., \& Sageie, J., 2000). It was obvious that the trend and research concern of previous studies have changed over time (Table 1).

Studies conducted before 1990 were mainly concerned on the design and safety aspect of the environments for children's play. Thus, the studies focused on playgrounds and streets in the neighbourhood. On the other hand, researchers also emphasised the effects of designs on children's developments. The evolution in the trend of studies can be seen starting from the early 1990s. More studies focused on a wider environment where the children grew up. It seems clear that most studies are commonly done in residential neighbourhood. 
Table 1: Trend of Studies in Children and the Outdoor Environments

\begin{tabular}{|c|c|c|c|}
\hline Years & $\begin{array}{c}\text { Types of } \\
\text { environment }\end{array}$ & Authors & Research Concern \\
\hline \multirow[t]{3}{*}{$1985-1989$} & Playground & $\begin{array}{l}\text { Wilkinson, P.F. } \\
\text { (1985), Heusser, C.P. } \\
\text { et al. (1986) }\end{array}$ & \multirow{3}{*}{$\begin{array}{l}\text { - Studies focus on a specific } \\
\text { environment. } \\
\text { - Many studies highlighted on } \\
\text { the design and safety } \\
\text { aspects of the play spaces/ } \\
\text { places and its impact on } \\
\text { children's development. }\end{array}$} \\
\hline & $\begin{array}{l}\text { Street } \\
\text { (neighbourhood) }\end{array}$ & $\begin{array}{l}\text { Tyler, F.B. et al. } \\
(1987)\end{array}$ & \\
\hline & School ground & Harvey, M.R. (1989) & \\
\hline \multirow[t]{3}{*}{$1980-1989$} & Neighbourhood & $\begin{array}{l}\text { Andel, J.V. (1990), } \\
\text { Wood, D. (1983), } \\
\text { Valentine, G., \& } \\
\text { McKendrick, J. (1997) }\end{array}$ & \multirow{3}{*}{$\begin{array}{l}\text { Studies focus on a wider } \\
\text { environment which is the } \\
\text { living surrounding of } \\
\text { children. } \\
\text { - Studies investigated the } \\
\text { factors influencing children's } \\
\text { used of immediate outdoor } \\
\text { environments, children's } \\
\text { experiences being outdoors } \\
\text { and impact on children's } \\
\text { developments. }\end{array}$} \\
\hline & Public places & $\begin{array}{l}\text { Lennard, H.L., \& } \\
\text { Lennard, S.H.C. } \\
(1992)\end{array}$ & \\
\hline & Playground & $\begin{array}{l}\text { Lowry. P. (1993), } \\
\text { Herrington, S., \& } \\
\text { Studtmann, K. (1998) }\end{array}$ & \\
\hline \multirow[t]{3}{*}{$2000-2010$} & $\begin{array}{l}\text { Natural } \\
\text { environment }\end{array}$ & $\begin{array}{l}\text { Fjertoft, I., \& Sageie, } \\
\text { J. (2000) }\end{array}$ & \multirow{3}{*}{$\begin{array}{l}\text { Studies focus on a wider } \\
\text { environment which is the } \\
\text { living surrounding of children } \\
\text { and other environments for } \\
\text { children's outdoor play. } \\
\text { - Studies investigated the } \\
\text { factors influencing children's } \\
\text { used of immediate outdoor } \\
\text { environments, children's } \\
\text { experiences being outdcors, } \\
\text { impact on children's } \\
\text { developments and the role } \\
\text { of design to encourage } \\
\text { children's activities in the } \\
\text { outdoor environment }\end{array}$} \\
\hline & Neighbourhood & $\begin{array}{l}\text { Kytta, M. (2004), } \\
\text { Taylor, A.F., et al. } \\
(2002) \text {, Prezza, M. } \\
(2007) \text {, Castonguay, } \\
\text { G., \& Jutras, S. } \\
(2009,2010)\end{array}$ & \\
\hline & School ground & $\begin{array}{l}\text { Dyment, J. E., etal. } \\
\text { (2009), Powell, M. } \\
\text { (2007), Ozdemir, A., } \\
\text { \& Yilmaz, O. (2008) }\end{array}$ & \\
\hline
\end{tabular}

As a result of the changes that occurred in the children's living surrounding, the studies were concerned on the factors influencing children's use of the immediate outdoor environments such as demographic factors, public space designs and provisions, sociocultural factors, safety and level of children's independent mobility. In conclusion, they found that the factors that limited children's use of outdoor environment in their neighbourhood have a negative impact on children's play experiences and developments. Low security and safety level and low physical qualities of the living environment are among the factors which reduce the potential for children's development. The trend of study continues with an extension to other environments such as school ground and the natural environment.

In the school ground, studies have been focusing on the physical environment and 
design of the play spaces in the school grounds, and its effect on children's physical activity and development. An evaluation was taken on the design and landscape qualities of the school ground, followed by an observation or behavioural mapping on children's activity level and play behaviour. Research on the natural environments has investigated the relationship between the natural attributes and children's developments. For example, the variety of vegetation and topography afforded versatile play which improved children's motor fitness (Fjørtoft, I., \& Sageie, J., 2000).

\subsection{Research undertaken with children in the outdoor environments}

It is important to understand several methodological issues concerning the common methods, subjects and parameters being measured in research undertaken with children in the outdoor environments. The review of literature relating to children's use of outdoor environments has shown that they primarily focused on middle childhood aged between 6 and 11-year-olds and applied interviews or questionnaires with children as well as observation on children's activity and behaviour. According to Prezza, M. (2007), questionnaires and interviews provide economical measures and allow the researcher to reach a wider population. Interview techniques are effective at understanding behaviour and behaviour change; however they do not provide quantifiable evidence, particularly in relation to developmental benefits of outdoor use. Interview and questionnaire are laid in the traditional social science methods in research with children. These traditional methods have been critiqued from several aspects; not least they ignore the power imbalances between adults and children, but also can project the authoritative stance of researchers, which may result in intimidation (Blerk, L.v., 2006). Observation is a technique to study more about children's behaviour (Bredekamp, S., 1987). Raw descriptive data on children is collected, and then are sorted, interpreted and quantified to search out trends and to make hypotheses. Video and audio recording (Lowry, P., 1993; Herrington, S., \& Studtmann, K., 1998), log and journal writing (Peterson, L., 1991; Castonguay, G., \& Jutras, S., 2009) and rating scales (Harvey, M.R., 1989; Taylor, A.F., et al., 2002) are some examples of methods for observing children's behaviour. They provide insights that are useful for planning strategies to meet children's need.

Twenty from the 30 studies were reviewed; middle childhood children were taken as the respondent or subject in their study. The selection of this children's stage may be influenced by the ability they can interpret their experiences and feelings in the outdoor environments. At this stage, children use the outdoor environment extensively (Chawla, L., 1992; Kellert, S.R., 2002). They also have the ability to demonstrate their preferences in the places they use and the activities they undertake in those places because they benefit from the increasing freedom to play outdoors without adults' supervision. As a result from increasing the autonomy that they have gained, usually the researchers did not have difficulties to obtain permission from their parents to allow their children to get involved in a study. In addition, primary childhood children are typically becoming less egocentric and more socio-eccentric at this age, as they have a greater understanding of their relationship 
with others (Black, J., et al., 1996), especially when they are playing outdoors. Furthermore, the increasing endurance and coordination enable them to enjoy many gross motor activities and games (Billman, J., \& Sherman, J.A., 1996). They perceive play in the outdoor environments which offer various exciting and challenging play elements, provide them the opportunity to choose, make decision, experiment, imagine and create new things.

\subsection{Factors that influence children's use of outdoor environments}

From this review, the influential factors in children's use of outdoor environment can be categorised into individual factors, physical factors and social factors (Table 2).

Table 2: Main factors influencing children's use of outdoor environments

\begin{tabular}{|c|c|c|}
\hline Category & Main Factors & Descriptions \\
\hline $\begin{array}{l}\text { Individual } \\
\text { factors }\end{array}$ & $\begin{array}{l}\text { Demographic } \\
\text { Socioeconomic status } \\
\text { Place's experiences } \\
\text { Attitude to active play }\end{array}$ & $\begin{array}{l}\text { Factors relating to age, gender and ethnic. } \\
\text { The status of family income either they are } \\
\text { from low income, medium income or high } \\
\text { income family. } \\
\text { Children's familiarity with places and specific } \\
\text { experiences with the places or elements. } \\
\text { Individual preferences and positive and } \\
\text { negative attitudes toward active place and } \\
\text { particular play spaces. }\end{array}$ \\
\hline $\begin{array}{l}\text { Physical } \\
\text { factors }\end{array}$ & $\begin{array}{l}\text { Design and quality of } \\
\text { facilities / play equipments } \\
\text { Environmental factors / } \\
\text { urban design / safety } \\
\text { Level of affordances }\end{array}$ & $\begin{array}{l}\text { Provision of facilities at public open spaces } \\
\text { including playgrounds, parks and the } \\
\text { accessibility. } \\
\text { Elements of urban design and street design } \\
\text { which influence choices of place for active } \\
\text { play. } \\
\text { Availability of functional elements in the } \\
\text { outdoor environments. }\end{array}$ \\
\hline $\begin{array}{l}\text { Social } \\
\text { factors }\end{array}$ & $\begin{array}{l}\text { Parental restriction } \\
\text { and level of children's } \\
\text { independence } \\
\text { Bad people and culture } \\
\text { Social aspects } \\
\text { Geographical perspective }\end{array}$ & $\begin{array}{l}\text { Parental fears cn the children's safety } \\
\text { increased the restriction to play outside, as } \\
\text { well as decreased children's autonomous } \\
\text { mobility. } \\
\text { Exposure to strangers, teenagers, syringes } \\
\text { and negative cultures. } \\
\text { Impact of friends, peers, neighbors in } \\
\text { children's play. } \\
\text { Social interaction between parents in } \\
\text { establishing local 'nom'. }\end{array}$ \\
\hline
\end{tabular}

This categorisation was based on the Ecological Models suggested by Owen, N., et al. (2000); there are unique interactions between individuals and their social and physical environments that may influence children's use of outdoor environments and their behaviours such as physical activities. For example, a child who is simply not interested in an outdoor active free-play may not be motivated to play outside, regardless of whether the environment provides a lot of physical and social affordances. The relationship between individual, social and physical environments, then, will structure the perceptions, and 
shaping of potential affordances (Kytta, M., 2002). Besides, the parental concern on the safety aspect of the physical and social environments may influence the level of parental restriction on children's play in the outdoor environment. Even though children have positive attitudes towards active play, a result from their parent's restriction may cause the play to be limited to their home yard. Thus, children cannot find affordances and the ignorance of affordances tend to decrease the motivation to move around and explore the environment (Kytta, M., 2004).

\subsubsection{Individual factors}

Demographic factors such as age and gender are among the common factors that influence children's place and play preferences. Older children and males are more independent to play outdoors. Young children with limited independent mobility, typically their access to outdoor play spaces are restricted to their own home's yard or a neighbour's yard, or the street directly outside their home (Prezza, M., 2007). Gender differences do not seem to be linked to different spatial abilities and children's experiences and enjoyment, but rather to the widespread social stereotype that allow males greater freedom to explore the environment. For example, girls were found more active in the home yard, while boys tended to be active at sport setting and private vacant areas, which were located away from their home (Blakely, K.S., 1994).

There is significant relationship between children's socioeconomic status and their experience playing outdoors. Children from low income families or deprived neighbourhoods are likely to play at the immediate surroundings and be active in their peer's or relative's yard more often (Veitch, J., et al., 2008), as a result of fewer resources of other play opportunities (Valentine, G., \& McKendrick, J., 1997). In contrast to children from high socioeconomic status, they are most frequently active at the parks, playgrounds, streets and indoor sport centres which are located slightly far from their homes (Veitch, J., et al., 2008), and are frequently accompanied by their parents.

Children's preferences to engage with active play in particular settings are influenced by their psychological affection and distinction experiences with those settings (Andel, J.V, 1990). Children's familiarity and proximity with a place become an important determinant of outdoor play (Cantanguay, G., \& Jutras, S., 2009). Children have a propensity to repeat their visit to a place which gave them good experiences and psychological affections. In addition, children's use of outdoor environments is also influenced by their attitude to active play; either they are "indoor kids" or "outdoor kids". "Indoor kids" seldom play outdoors; they prefer sedentary activities like video or computer games, drawing and watching television at home (Veitch, J., et al., 2006).

\subsubsection{Physical factors}

Challenging play equipment is an important factor that attracts children to play outdoors (Hart, C.H., \& Sheehan, R., 1986; Veitch, J., et al., 2008). For example, they found that the traditional playground which is associated with various elements and offered more 
functional play behaviour is most frequently used by children compared to the contemporary playground. However, many public playgrounds are designed with a lack of complexity, variety and opportunity for children to manipulate and explore (Heusser, C.P., et al., 1986); consequently cause the playgrounds to be used un-frequently by the children because it was not challenging and appealing for children of all ages (Veitch, J., et al., 2006). Most parents were dissatisfied with the public provision and opportunities for children's play in their neighbourhood due to the poor play facilities and inadequate provision predominates for all social groups (Valentine, G., \& McKendrick, J., 1997).

Children valued the relatively diversified affordances offered by the play environment such as parks and playgrounds which allowed them to take part in their favourite activities. Places that attract more children are those that offer the greatest variety of affordances for active play (Castonguay, G., \& Jutras, S., 2010). For example, a variety of elements in the school ground promoted more physical activities among children; vigorous, moderate or sedentary activity, and appealed more broadly to children of varying interests and abilities, and it also promoted social interaction and cognitive development (Dyment, J.E., et al., 2009).

However, the increased traffic on street hindered children from being accessible to the parks or open spaces (Hüttenmoser, M. 1995). Children lost the opportunities to be active at outdoors due to the changing function of residential streets, which acted as a barrier rather than resource for children's play (Veitch, J., et al., 2006). Children living in cul-desacs (low-walkability neighbourhood) had greater autonomy to play outdoors. Cul-de-sacs mostly benefitted the young children; it offered opportunities for the parents to supervise their children's play, and parents perceived the spaces as a safe place for children to play. However, cul-de-sacs restricted the play of older children, as a result of low street connectivity. Thus, grid-style street (high-walkability neighbourhood) facilitates play and social interaction among older children (Holt, N.L., et al., 2008).

\subsubsection{Social factors}

Parental safety concerns became the main factors that restricted children's autonomous mobility to play in the outdoor environments independently (Blakely, K.S., 1994; Prezza, M., 2007). Parental safety concerns mainly related to the fears of strangers, teenagers and road traffic (Veitch, et al, 2008; Castonguay, G., \& Jutras, S., 2010), as well as exposure of their children to the negative cultures especially the boys (Valentine, G., \& McKendrick, J., 1997). This concern mainly occurred in low socioeconomic status neighbourhoods where parents reported teenagers loitering in parks and other public spaces. These factors appeared to limit children's ability to play in places away from home without adults' supervision. Children's independent mobility is one of the factors that influences the actualised affordances in the outdoor environments; children's independent mobility shrinks significantly with the increasing degree of urbanisation (Kytaa, M., 2004). 
In addition, the presence of other children seems to be an important determinant in a child's decision to play outdoor (Wilkinson, P.F., 1985; Veitch, J. et al., 2006). Children are much more likely to play outdoors if they have friends or other children of the same age to play with. These factors show the importance of social interaction in children's outdoor play. According to Andel, J.V. (1990), the presence of other children also gave negative effects on children's outdoor play. As an example, children may avoid places where their play is disrupted or where there are bullied by other children.

Another study conducted by Valentine, G., \& McKendrick, J. (1997) found that social interaction between mothers was an important part in establishing local 'norms' about how far away from home and for how long children should be allowed to play. The pressures they experience from each other imposed strict restrictions on their children's play, in order to fit with the local 'common sense' constructions about what it means to be a 'good' mother.

\subsection{Conclusions}

For a child, play is important for his/her developmental needs. Physical activities that have occurred in children's play have been shown to be important for children's immediate social, mental and physical health. Playing in the outdoor environment that offers various affordances can stimulate their senses and generate their cognitive skills. Thus, many studies generally investigated the location in which children were engaged in most of their active play and the factors that influenced their choice of location and activity, as well as their experiences in the outdoor environments.

Regarding the methodologies used, both qualitative and quantitative researches have been carried out, where questionnaires, interviews and observations were the common ones being applied. These traditional methods sometime ignore the power of imbalances between adults and children, which may result in intimidation. Thus, it is important to do research with children rather than on children. Therefore, the research has to be childrencentered, which reflects upon special consideration on the groups being studied, ensuring children's participation in research by working with them to select methods that are appropriate to both the research aims and to the contexts in which they live, as well as to identify children's needs and factors that influence their decisions to play outdoors.

\section{Acknowledgement}

The study was funded by the Ministry of Higher Education of Malaysia and Universiti Sains Malaysia under the Academic Staff Training Scheme (ASTS). 
Aziz, N.F., \& Said, I. / Asian Journal of Environmen-Behaviour Studies, ajE-Bs, 2(5) Oct / Dec 2017 (p.97-108)

\section{References}

Andel, J. V. (1990). Places children like, dislike, and fear. Children's Environments Quarterly 7(4), 24-31.

Billman, J., \& Sherman, J. A. (1996). Observation and Participation in Early Childhood Setting: A Practicum Guide. Sydney: Allyn and Bacon.

Black, J., Puckett, M., \& Bell, M. (1996). The Young Children. New York: Merril.

Blakely, K. S. (1994). Parents' conceptions of social dangers to children in the urban environment. Children's Environments, 11(1), 20-35.

Blerk, L. v. (2006). Working with Children in Development. In V. Desai \& R. B. Potter (Eds.), Doing Development Research. London: SAGE Publications.

Bredekamp, S. (1987). Developmentally Appropriate Practice In Early Childhood Programs Serving Children from Birth through Age 8. Washington DC: National Association for the Education of Young Children.

Castonguay, G., \& Jutras, S. (2009). Children's appreciation of outdoor places in a poor neighborhood. Journal of Environmental Psychology, 29, 101-109.

Castonguay, G., \& Jutras, S. (2010). Children's use of the outdoor environment in a low-income Montreal neighborhood. Children, Youth and Environments, 20(1), 200-230.

Chawla, L. (1992). Childhood Place Attachment. In Altman, Irwin \& Setha M. Low (Eds.), Place Attachment (Vol. 12, pp. 63-86). New York: Plenum Press.

Dyment, J. E. (2005). Green school grounds as sites for outdoor learning: Barriers and opportunities. International Research in Geographical and Environmental Education, 14(1), 28-45.

Dyment, J. E., Bell, A. C., \& Lucas, A. J. (2009). The relationship between school ground design and intensity of physical activity. Children's Geographies, 7(3), 261-276.

Fjørtoft, I., \& Sageie, J. (2000). The natural environments as a playground for children landscape description and analyses of a natural playscape. Landscape and Urban Planning, 48, 83-97.

Gibson, J. J. (1979). The Ecological Approach to Visual Perception. Boston: Houghton-Mifflin.

Hart, C. H., \& Sheehan, R. (1986). Preschoolers' play behavior in outdoor environments: Effects on traditional and contemporary playgrounds. American Educational Research Journal, 23(4), 668-678

Hart, R. A. (1997). Children's Participation: The theory and practice of involving young citizens in community development and environmental care. London: Earthscan Publications.

Harvey, M. R. (1989). Children's experience with vegetation. Children's Environments Quarterly, 6(1), 36-43.

Heft, H. (1988). Affordances of children's environments: A functional approach to environmental description. Children's Environments Quarterly, 5(3), 29-37. 
Herrington, S., \& Studtmann, K. (1998). Landscape interventions: New directions for design of children's outdoor play environments. Landscape and Urban Planning, 42, 191-205.

Heusser, C. P., Adelson, M., \& Ross, D. (1986). How children use their elementary school playgrounds. Children's Environments Quarterly, 3(3), 3-11.

Holt, N. L., Spence, J. C., Sehn, Z. L., \& Cutumisu, N. (2008). Neighborhood and developmental differences in children's perceptions of opportunities for play and physical activity. Health \& Place, 14, 2-14.

Hüttenmoser, M. (1995). Children and their living surroundings: Empirical investigations into the significance of living surroundings for the everyday life and development of children. Children's Environments, 12(4), 1-17.

Kellert, S. R. (2002). Experiencing Nature: Affective, Cognitive, and Evaluative Development in Children. In P. H. Khan \& S. R. Kellert (Eds.), Children and Nature (pp. 117-151). Cambridge: MIT Press.

Kernan, M. (2010). Outdoor affordances in early childhood education and care setting: Adults' and children' perspectives. Children, Youth and Environments, 20(1), 152-177.

Kytta, M. (2002). Affordances of children's environments in the context of cities, small towns, suburbs and rural villages in Finland and Belarus. Journal of Environmental Psychology, 22, 109-123.

Kytta, M. (2004). The extent of children's independent mobility and the number of actualized affordances as criteria for child-friendly environments. Journal of Environmental Psychology, 24, 179-198.

Lennard, H. L., \& Lennard, S. H. C. (1992). Children in public places: Some lessons from European cities. Children's Environments, 9(2), 56-75.

Lowry, P. (1993). Privacy in the preschool environment: Gender differences in reaction to crowding. Children's Environments, 10(2), 46-61.

Matthews, M. H. (1992). Making Sense of Places. Harvester Wheatsheaf, Hemel Hempstead.

McDevitt, T. M., \& Ormrod, J. E. (2002). Child Development and Education. New Jersey: Merrill Prentice Hall.

Min, B., \& Lee, J. (2006). Children's neighborhood place as a psychological and behavioral domain. Journal of Environmental Psychology, 26, 51-71.

Olds, A. R. (1989). Psychological and Physiological Harmony in Child Care Center Design. Children's Environment Quarterly, 6(4), 8-16.

Owen, N., Leslie, E., Salmon, J., \& Fotheringham, M. (2000). Environmental determinants of physical activity and sedentary behavior. Exercise Sport Sciences Review, 28(4), 153-158.

Ozdemir, A., \& Yilmaz, O. (2008). Assessment of outdoor school environments and physical activity in Ankara's primary schools. Journal of Environmental Psychology, 28, 287-300.

Peterson, L., Cook, S. C., Little, T., \& Schick, B. (1991). "Mom lets me go there": The role of environment and supervision in children's minor injuries. Children's Environments Quarterly, 8(3/4), 15-23.

Powell, M. (2007). The hidden curriculum of recess. Children, Youth and Environments, 17(4), 86-106. 
Aziz, N.F., \& Said, I. / Asian Journal of Environmen-Behaviour Studies, ajE-Bs, 2(5) Oct / Dec 2017 (p.97-108)

Prezza, M. (2007). Children's independent mobility: A review of recent Italian Literature. Children, Youth and Environments, 17(4), 293-318.

Reed, E. S. (1996). Encountering the World: Toward an Ecological Psychology. Oxford: Oxford University Press.

Simmons, D. A. (1994). Urban children's preferences for nature: Lessons for environmental education. Children's Environments, 11(3), 28-40.

Taylor, A. F., Kuo, F. E., \& Sullivan, W. C. (2002). Views of nature and self-discipline: Evidence from inner city children. Journal of Environmental Psychology, 22, 49-63.

Tyler, F. B., Holliday, M. Y., Tyler, S. I., Echeverry, J. J., \& Zea, M. C. (1987). Street children and play. Children's Environments Quarterly 4(4), 13-17.

Valentine, G., \& McKendrick, J. (1997). Children's outdoor play: Exploring parental concerns about children's safety and the changing nature of childhood. Geoforum, 28(2), 219-235.

Veitch, J., Bagley, S., Ball, K., \& Salmon, J. (2006). Where do children usually play? A qualitative study of parents' perceptions of influences on children's active free-play. Health \& Place, 12, 383-393.

Veitch, J., Salmon, J., \& Ball, K. (2008). Children's active free play in local neighborhoods: A behavioral mapping study. Health Education Research, 23(5), 870-879.

Wilkinson, P. F. (1985). Safety in children's play environment. Children's Environments Quarterly 2(4), 9-12.

Wood, D. (1993). Ground to stand on: Some notes on kid's dirt play. Children's Environments, 10(1), 1-22. 